\title{
Temporal Variation of Rainfall in the Bagmati River Basin, Nepal
}

\author{
${ }^{1}$ Rajendra Man Shrestha and ${ }^{2}$ Azaya Bikram Sthapit \\ ${ }^{1}$ Padmakanya Multiple Campus, Kathmandu, Nepal \\ ${ }^{2}$ Central Department of Statistics, Tribhuvan University, Kathmandu, Nepal \\ e-mail: rajendramanshrestha65@gmail.com
}

\begin{abstract}
The main aim of the study was to identify the temporal variation of rainfall in the Bagmati River basin, Nepal using data available at Department of Hydrology and Meteorology, Government of Nepal. The time series data for the period of 1981-2008 were analyzed by using non-parametric Mann-Kendal test, Spearman's' Rho and a parametric linear regression. The results showed that there was a significantly increasing upward trend of the annual mean of weighted areal rainfall, with a rate of $2.2 \mathrm{~mm}$ per year. Trend analysis of the monthly time series of weighted areal rainfall showed a significant upward trend in the months of summer monsoon season (June and July). However, there were no such significant result in the other season/months. The increasing trend in the summer monsoon might lead to severe flooding in future.
\end{abstract}

Key words: ENSO, ITCZ, linear regression, Mann-Kendall Test, Spearman's rho test

\section{Introduction}

The atmo sphere is a complex natural system that is essential to support lifeon Earth. The precipitation is one of the most important components in the atmosphere and it has direct influences on life on the earth. Past studies have primarily focused on process and patterns of precipitation. Weather and climatic variability influences people's livelihoods and other environmental phenomena (IPCC 2001c). The weather is characterized by precipitation, temperature, wind, solar radiation, clouds, air pressure and humidity (IPCC 2001c, Oliver \& Hidore 2003). Climate is the average of weather conditions and their variability over a period of time that range from months to thousands or millions of years (Chaulagain, 2006, Graedel and Crutzen 1993).

Many studies suggest that both natural and anthropogenic activities contribute for an increased concentration of green gas emission (IPCC 2001c). IPPC reports suggest that average global temperature increased by approximately $0.6 \pm 0.2^{\circ} \mathrm{C}$ during the $20^{\text {th }}$ century and this trend was the greatest one known to science. In addition, the warming rate became even more pronounced during the second half of the last century. This was due to increased in anthropogenic greenhouse gas concentrations in the atmosphere (Graedel \& Crutzen 1993, IPCC 2001a).

According to the IPCC fourth report (Parry et al.2007) global warming will result in decreasing water availability and increasing drought in the mid-latitudes and semi arid low latitudes. The report also suggested an increasing trend of mean annual rainfall in South Asia while the seasonal distribution has not been clear yet.

The summer monsoon (June-September) brings most of rainfall in the South Asia, including in Nepal and is accompanied by a northwesterly airflow from the Bay of Bengal. The climate of Nepal is dominated by monsoon and about $80 \%$ of annual precipitation occurs during the summer monsoon (Babel et al. 2013). The amount of precipitation varies considerably at places due to the non-uniform rugged terrain (Shankar and Shrestha 1985). In the winter, the land area of Asia gets much colder than adjoining seas and becomes the high pressure area. Therefore, the air moves from the land to sea in the winter (Critchfield 2002). However, the monsoon does not begin abruptly. There 
is a gradual transition from the dry winter season to the summer monsoon as a result of the pre-monsoon convective rains, which are frequently accompanied by thunderstorms. Moreover, the winter precipitation is caused by western disturbances having their origin in Mediterranean Sea.

Nepal, which is located in the northern limit of the tropics, has a wide variations of climate, ranging from subtropical in the south, warm and cool in the hills to cold in the mountains within a horizontal distance of 200 km (Shankar \& Shrestha 1985, Chalise 1994).

The thermal regime in the vast Eurasian region, the size of the Inter-tropical convergence zone (ITCZ) and the resulting general atmospheric circulation dominates the precipitation of Nepal. The onset and retreat of the southeasterly summer monsoon is associated with the movement northwards and southwards of the ITCZ (Nayava 1980). The monsoon precipitation in Nepal is found to be related with EI Nino and large scale climatic parameters (Shrestha et al, 2000). Past studies have suggested an influence of El Niño Southern Oscillation (ENSO) in the rainfall over Nepal. Shrestha et al. (2000) reported that summer monsoon rain over Nepal (SMRN) was higher (lower) in relation with positive (negative) Southeastern oscillation index (SOI) during 1957-1988. Yadav et al. (2007) found a significant relation between northwestern Indian winter precipitation and SOI, and suggested that sea surface temperature (SST) had an important role in the equatorial Indian Ocean. Past studies are focused on rainfall variability taking influences of ENSO or ITCZ or large scale climatological parameters although there is an influence of orography at locals.

Kothyari and Singh (1996) showed that average annual rainfalls and annual number of rainy days were at decreasing for the period 1961-1989. Similarly, Nakawo et al. (1994) found a decreasing trend of precipitation for the period 1951-1980 at the other side of the Himalaya - in China. Similarly, Rupa Kumaretal.(2002) concluded that monsoon rainfalls were trendless during the last four decades and were random in nature in all over India a long period of time. In Nepal, Shrestha et al. (2000) reported that there was no distinct long term trend in the rainfall records during 1948-1994 although there was significant variations on annual/ and decadal time scales. However, Sharma et al. (2001a) found an increasing trend of observed rainfall pattern in the Koshi river basin in eastern Nepal. However, the trends were widely varied in the seasons and in sites. Barros et al. (2000) suggested TRMM satellite-derived rainfall estimates to be more accurate at low than at high elevations. Analysis of a 3-year data set from high-altitude gauges showed annual precipitation amounts of up to $5000 \mathrm{~mm}$ at elevations up to $4500 \mathrm{~m}$ above sea level. Lang and Barros (2002) investigated monsoon onset in 1999 and 2000 with respect to large-scale circulation and noted that an eightfold difference in rainfall estimatics in the rain gauges due to the effect of small-scale terrain features.

Barros and Lang (2003) identified a postmidnight peak in rainfall during June 2001, attributed to strong convection as a result of the interaction of ambient monsoon flows with the southerly slopes, modulated by diurnal variability in atmospheric state. Bookhagen B. and Burbank W. (2006) showed the outer rainfall peak occurs along the Southern margin of the Lesser Himalaya within a narrow band with a mean elevation $(0.9 \pm 0.4 \mathrm{~km})$ and a mean relief $(1.2 \pm 0.2 \mathrm{~km}$. Shrestha et $a l$. (2008) showed an increasing trend in total and heavy precipitation events in the most of stations. However, the systematic difference has not been observed in extreme precipitation trend between hills and low land southern plains of Terai.

Shrestha et al. (2012) showed that there is a strong relationship between rainfall and elevation in the central Himalayan region (CHR) for pre-monsoon and monsoon seasons on the basis of the 11 year (19982008) high-spatial-resolution TRMM PR 2A25 nearsurface rainfall data. Shrestha et al. (2014) found that most extreme precipitation increases in the South Asia average, consistent with globally average results. Shrestha et al. (2015) studied spatial and temporal variability of rainfall in the Gandaki River Basin of Nepal Himalaya with use of APHRODITE precipitation and found that the post-monsoon, pre-monsoon and winter rainfalls were decreasing significantly in most of the zones but monsoon rainfall was increasing. Mairura et al. (2015) found $90 \%$ chance of below cropping threshold rainfall (500 $\mathrm{mm}$ ) exceeding $258.1 \mathrm{~mm}$ during short rains in Embu for one year retuned by using the interpolation techniques in eastern Kenya

The Bagmati river is the most important river basin of Nepal with monsoon rain and springs as main sources. 
Rajendra Man Shrestha and Azaya Bikram Sthapit/Temporal Variation of Rainfall......

Therefore the basin plays a significant role in water supply of water for drinking and irrigation in the Kathmandu valley. The fluctuations in rainfall across the basin are the major determinants of livelihood of people. It is therefore necessary to study annual rainfall pattern and its seasonal variations, which are critical for making policies and plans. There is a huge research gap in defining temporal variability both in annual and monthly rainfall regimes across the Bagmati River Basin on the basis of station-aggregated data in the period of 1981-2008. The work reviewed above has largely dealt with the summer monsoon period and annual rainfall totals. Therefore, there is a need to consider the seasonal and annual behavior of rainfall over the year. This aim is achieved through the following specific objectives: (a) to know the status of annual trend/variability and seasonal fluctuation of the rainfall, (b) to test the long-term annual trend of the annual rainfall data, and (c) to test the monthly seasonal trend of the rainfall across the study site.

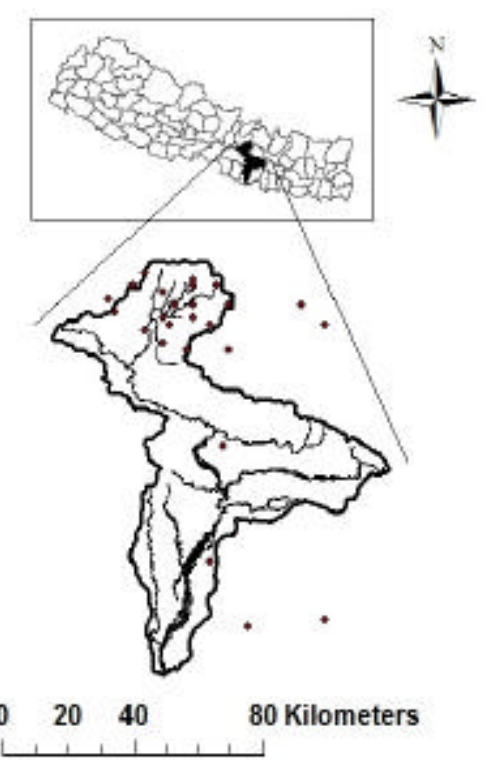

Fig. 1a. Map of Nepal and the Bagmati River Basin with its tributaries and 25 stations

\section{Study site}

The Bagmati River basin (Figure 1a) originates from the Shivapuri hills of the Mahabharata range and drains out of Nepal (Jha 2002). Its main tributaries Manohara, Bishnumati, Kulekhani, Kokhajor, Marin, Chandi, Jhanjh and Manusmara-located within the middle mountain of Nepal (26 $45^{\circ}-27^{\circ} 49^{\prime} \mathrm{N}-85^{\circ} 02^{\prime}$ $85^{\circ} 27^{\prime}$ E) and occupy an area of 3,604.44 $\mathrm{km}^{2}$ (referring to 25 stations). Babel et al. (2013) has mentioned that the elevation of the Bagmati River basin ranges from $80 \mathrm{~m}$ in Terai in the southern part of Nepal to $2900 \mathrm{~m}$ in the Mahabharata range in the north. Its length is about $51 \mathrm{~km}$. The climatic condition of the Bagmati River basin is quite changing due to the intrinsic topography. Temperature generally decreases with elevation and becomes low in winter and high in summer. It seems the whole Bagmati River basin is divided according to its climatic zone. Cool temperate humid zone lies between $2000-3000 \mathrm{~m}$. It covers only about 5 percent of the basin, where the mean annual temperature varies between $15^{\circ}$ and $20^{\circ} \mathrm{C}$. Warm temperate humid zone lies between $1000-2000 \mathrm{~m}$. It covers about 60 percent part of the basin, where the mean annual temperature varies from $10^{\circ}$ to $20^{\circ} \mathrm{C}$. Sub-tropical humid zone lies below $1000 \mathrm{~m}$. It covers southern part of the basin with the Siwaliks and Terai, where the annual temperature range is between $20^{\circ}$ and $30^{\circ} \mathrm{C}$. The mean relative humidity varies between $70 \%$ and $86 \%$. Department of Hydrology and Meteorology reported that the annual rainfall in the basin is about $1800 \mathrm{~mm}$ with 80 percent of the total rain in the monsoon season.

\section{Data and Methodology \\ Data}

According to Sharma et al. (2004). there are five types of stations: Precipitation, Climatology, Synoptic, Aerosynoptic and Agro-meteorology. Stations are placed with elevation ranging from $131 \mathrm{~m}$ at Karmaiya, Sarlahi district to $2163 \mathrm{~m}$ at Nagarkot, Kathmandu district and covers different parts of the Bagmati River Basin. However, the present study considered the daily rainfall data only for 25 stations due to incomplete time-series data for the period of Jan 1981-Dec 2008. By using Thiessen Polygon method, daily rainfall data were aggregation over the 25 stations. Thus, weighted areal rainfall was generated for each day of time-series of 19812008. It has been common practice to assume that at least ten years of daily observations are necessary to produce the relevant base statistical parameters for most meteorological data, and so are 30 years for rainfall (VarelaLopes et al. 2014).

\section{Descriptive analysis}

To summarize the rainfall changes over the study period, the standardized rainfall index of time series is computed for the Bagmati River Basin from the period of 1981-2008. The method is: $Z_{i}=\frac{\left(X_{i}-\mu\right)}{\sigma}$, where $Z_{\mathrm{i}}$ is 
the standardized rainfall index; $\mathrm{X}_{\mathrm{i}}$ is an annual sum of weighted areal rainfall for the basin; $\mu(=1803.87 \mathrm{~mm})$ and $\mathrm{s}(=354.85 \mathrm{~mm})$ are mean and standard deviation of the period. This index will describe the nature of wetness or dryness in the study area with a potential effect of ENSO with support of the literatures on the rainfall pattern.

\section{Trend analysis}

Statistical tests detect the changes in a time series which can occur steadily (a trend), abruptly (a stepchange or jump) or in a more complex form. For such detection and understanding the rainfall pattern, there are various methods to test for trend, change and randomness in time series. According to this, MannKendall, Spearman's Rho and linear regression methods are used for trend detection in the time series.

Mann-Kendall Test: This method tests whetherthere is a trend in the time series data. It is a non-parametric test. The $n$ time series values $\left(X_{1}, X_{2}, X_{3}, \ldots . ., X_{n}\right)$ are replaced by their relative ranks $\left(R_{1}^{2}, R_{2}^{3}, R_{3}, \ldots . ., R_{n}\right)$ (starting at 1 for the lowest up to $\mathrm{n}$ ). The test statistic $\mathrm{S} \quad: \mathrm{S}=\sum_{\mathrm{i}=1}^{\mathrm{n}-1} \sum_{\mathrm{i}=\mathrm{i}+1}^{\mathrm{n}} \operatorname{sign}\left(\mathrm{R}_{\mathrm{j}}-\mathrm{R}_{\mathrm{i}}\right)$, where Sign $(\mathrm{E}-\mathrm{R})=1$ or 0 or -1 if $\left(\mathrm{R}_{\mathrm{j}}-\mathrm{R}_{\mathrm{i}}\right)>0$ or 0 or $<$

0 respectively. $R_{i}$ and $R_{j}$ are the annual values in years $j$ and $i, j>1$ respectively. If the null hypothesis $H_{o}$ is true, then $S$ is approximately normally distributed with: $\mu=0, s=n(n-1)(2 n+5) / 18$. The Z-statistic is therefore (critical test statistic values for various significance levels can be obtained from normal probability tables): $\mathrm{Z}=|\mathrm{S}| / \mathrm{s}^{0.5}$. A positive value of $\mathrm{S}$ indicates that there is an increasing trend and vice versa.

Spearman's Rho Test: This is a rank-based test that determines whether the correlation between two variables is significant in trend analysis. One variable is time (years) and the other variables corresponds with the time series data. Like the Mann-Kendall Test, the $\mathrm{n}$ time series values are replaced by their ranks.

The test statistic $\rho_{s}=S_{X Y} /\left(S_{X} S_{Y}\right)^{0.5}$, where

$\mathrm{S}_{\mathrm{X}}=\sum_{\mathrm{i}=1}^{\mathrm{n}}\left(\mathrm{X}_{\mathrm{i}}-\overline{\mathrm{X}}\right)^{0.5}, \mathrm{~S}_{\mathrm{Y}}=\sum_{\mathrm{i}=1}^{\mathrm{n}}\left(\mathrm{Y}_{\mathrm{i}}-\overline{\mathrm{Y}}\right)^{0.5}$ and

$S_{X Y}=\sum_{i=1}^{n}\left(X_{i}-\bar{X}\right)\left(Y_{i}-\bar{Y}\right) x_{i}($ time $), y_{i}($ variable of interest), $x$ and $y$ refer to the ranks of $x, y, S_{x}$ and $S_{y}$ have the same value in a trend analysis ). For large samples, the quantity $\rho_{\varepsilon} \sqrt{(n-1)}$ is approximately normally distributed with mean of 0 and variance of 1 . Critical test statistic values for various significance levels can beobtained from normal probability tables.

Simple linear regression: This is a parametric test that assumes that the data are normally distributed. It tests whether there is a linear trend by examining the relationship between time $(\mathrm{x})$ and the variable of interest $(\mathrm{y})$. The regression gradient is estimated by: $\mathrm{b}=\frac{\sum_{\mathrm{i}=1}^{\mathrm{n}}\left(\mathrm{x}_{\mathrm{i}}-\overline{\mathrm{X}}\right)\left(\mathrm{Y}_{\mathrm{i}}-\overline{\mathrm{Y}}\right)}{\sum_{\mathrm{i}=1}^{\mathrm{n}}\left(\mathrm{X}_{\mathrm{i}}-\overline{\mathrm{X}}\right)^{2}}$ and $\mathrm{a}=\overline{\mathrm{Y}}-\mathrm{b} \overline{\mathrm{X}}$. The test statistic $\mathrm{S}$ is: $\mathrm{b} / \mathrm{s}$, where $\sigma=\sqrt{\frac{12 \sum_{\mathrm{i}=1}^{\mathrm{n}}\left(\mathrm{Y}_{\mathrm{i}}-\mathrm{a}-\mathrm{b} \mathrm{X}_{\mathrm{i}}\right)}{\mathrm{n}(\mathrm{n}-2)\left(\mathrm{n}^{2}-1\right)}}$. The test statistic $\mathrm{S}$ follows a Student-t distribution with $\mathrm{n}-2$ degrees of freedo m under the null. The linear regression test assumes that the data are normally distributed and that the errors (deviations from the trend) are independent and follows the same normal distribution with zero mean.

Cumulative Deviation Test: The purpose of this method is to detect a change in the mean of a time series after $m$ observations under normality assumption: $\mathrm{E}\left(\mathrm{X}_{\mathrm{i}}\right)=\mu$ for $\mathrm{i}=1,2,3, \ldots . \mathrm{m}$ and $\mathrm{E}\left(\mathrm{X}_{\mathrm{i}}\right)=\mu+$ " for $\mathrm{i}=\mathrm{m}+1, \mathrm{~m}+2, \ldots . \mathrm{n}$. where $\mu$ is the mean prior to the change and "is the change in the mean. The cumulative deviation from the means are calculated as $\mathrm{S}_{\mathrm{o}}{ }^{*}=0$ and $\mathrm{S}_{\mathrm{k}}^{*}=\sum_{\mathrm{i}=1}^{\mathrm{k}}\left(\mathrm{X}_{\mathrm{i}}-\overline{\mathrm{X}}\right)$, for $\mathrm{k}=1,2,3, \ldots \ldots, \mathrm{n}$ and the rescaled adjusted partial sums are obtained by dividing $\mathrm{S}_{\mathrm{k}}{ }^{*}$ values by the standard deviation: $\mathrm{S}_{\mathrm{k}}{ }^{*}=$ $\mathrm{S}_{\mathrm{k}}^{*} / \mathrm{D}_{\mathrm{X}} \cdot \mathrm{D}_{\mathrm{X}}^{2}=\sum_{\mathrm{i}=1}^{\mathrm{n}} \frac{\left(\mathrm{X}_{\mathrm{i}}-\overline{\mathrm{X}}\right)^{\mathrm{z}}}{\mathrm{n}}$. The test statistic $\mathrm{Q}$ is: $\mathrm{Q}=$ $\max \left|S_{k}^{* *}\right|$ and is calculated for each year, with the highest value indicating the change point. A statistical analysis can be performed using SPSS v 20.0 and TREND V1.02 software (Grayson et al. 1996).

\section{Results and Discussion Descriptive analysis Seasonal variability}

Figure 1 presents a seasonal rainfall regime in the Bagmati River basin. The rainfall regime was characterized by two distinct periods: dry and wet 
Rajendra Man Shrestha and Azaya Bikram Sthapit/Temporal variation of Rainfall......

seasons. April through October correspond to the wet season. Although the first four months are considered as dry, sporadic rainfall occurrence is common, mostly from November to January. This is referred as the transition months. November through February are considered as the dry months. On contrary to the dry months, March, April and May are considered as pre- monsoon months and June-to-September are considered as monsoon months or wettest season. Similarly, October to November are considered as postmonsoon season. The month of July was standing out as the wettest month on the average and had 526 $\mathrm{mm}$. It was followed by months August and September.

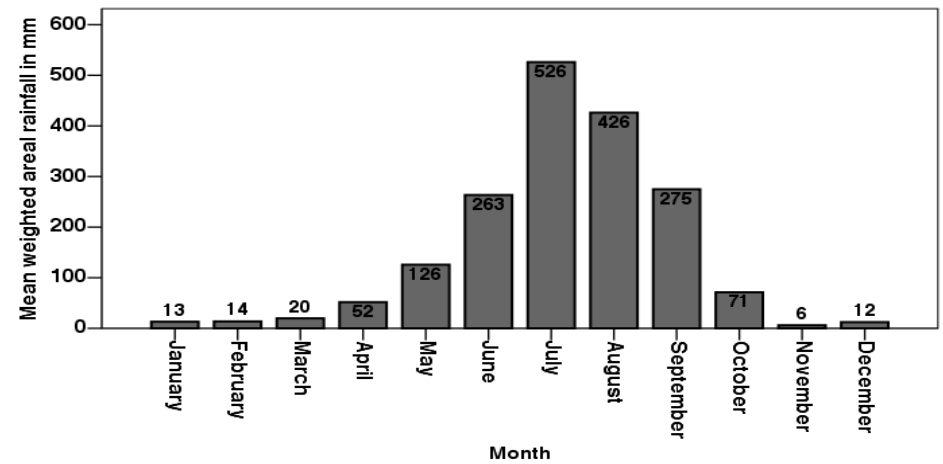

Fig.1b. Mean monthly weighted areal rainfall for the period of 1981-2008

The amount of the rainfall is highly varied due to the seasonal effect and hence it is interesting to note that the wetter months generally exhibit greater rainfall variability (Fig. 1b). These results suggest that the Bagmati River basin rainfall has a strong intra-seasonal variability. This knowledge of seasonal rainfall pattern over the basin should provide valuable information to the concerned government or non-government agencies for managing and developing the hydrologic infrastructures like barrage, water supply and irrigation and other relevant projects like flood controlling mechanism.

\section{Long-term variability}

Figure 2 presents the results of the standardized rainfall index time series computed for the Bagmati River Basin for period 1981-2008. Here total rainfall for each year (within \pm horizontal lines, i.e., \pm one standard deviation (SD)), are considered "normal" year (Varela-Lopes et al. 2014). In general, majority of year are normal years in term of yearly rainfall volunes (Fig. 2). However, there are some anomalies between period of 1981-1983, This period belongs to dry year. Similarly, the anomalies in 2002, 2004 and 2007 were above normal and thus belong to wet year. In order to examine interannual variability of the rainfall, Sigdel etal.(2012) reported that the most frequently cited index is Southern Oscillation Index (SOI), eventually represents ENSO. According to them, the positive (negative) SOI indicates La Niña (EI Niño) that corresponds to cold (warm) in Niño 3 region $\left(5^{\circ} \mathrm{N}-5^{\circ} \mathrm{S}\right.$, $\left.170^{\circ} \mathrm{W}-120^{\circ} \mathrm{W}\right)$ in the eastern pacific.

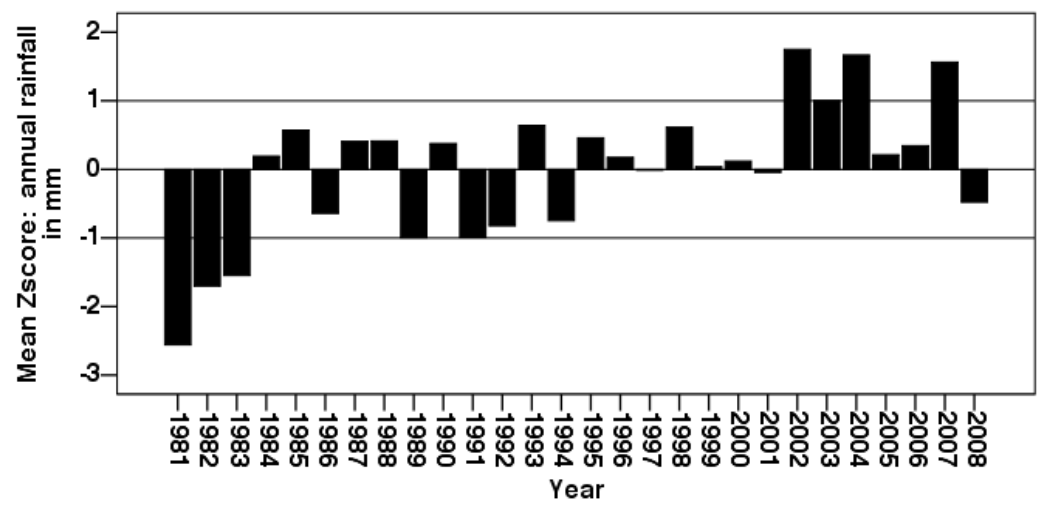

Fig.2. Time evolution of the standardized rainfall index for the period of 1981-2008 
They added that EI Nino year were 1972, 76, 77, 82, 87, 91, 93, 94, 97 and 2002. Similarly, La Nina year were 1974, 75, 81, 88, 96 and 1998. This statement was also supported by Varela-Lopes et al. (2014). According to them, 1987 and 1994 were EI Nino years and reported them as the wettest and driest years within the study period. But it is seen that these years (e.g., 1987 and 1994) were not more wetted and driest years in the Bagmati River basin as they both lie within \pm 1 SD. It means that there was no effect or very little effect on the rainfall regime in the basin since all of these years are normal. Contrary to EI Nino in 2002, the rainfall amount seemed above normal. This also depicts the positive impact in producing heavy rainfall amount in the study area. However, Shrestha (2000) and Sigdel et al. (2012) had demonstrated that summer monsoon over Nepal brought more rainfall and was correlated with La Nina (EI Nino). However, there is an increasing trend of rainfall pattern despite having some fluctuations in the study area (Fig. 3).

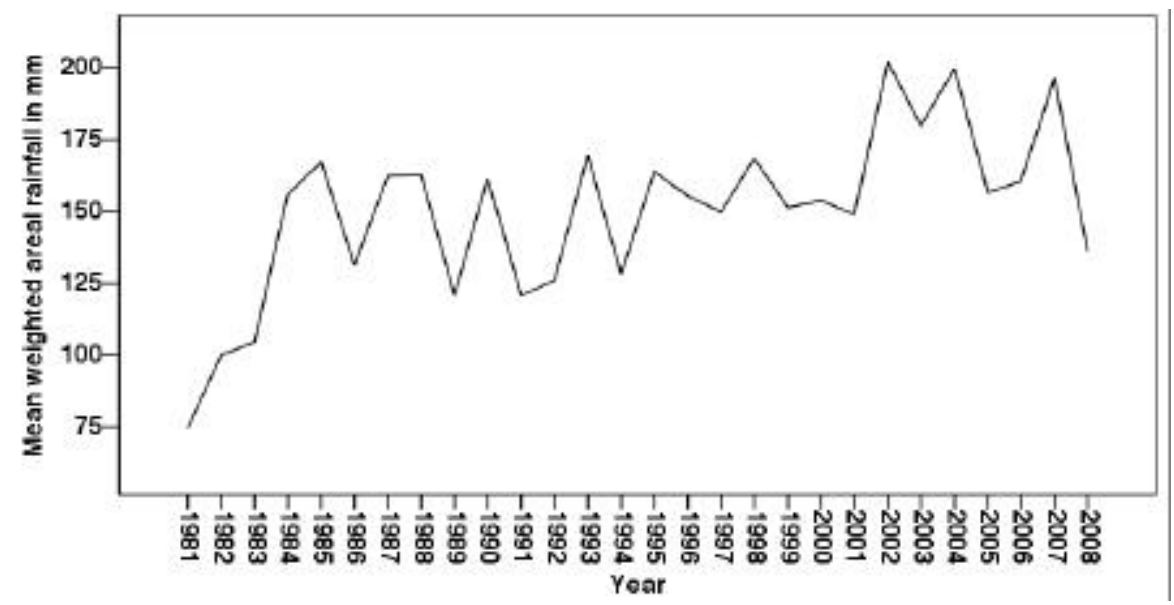

Fig.3. Time series plot of Annual mean weighted areal rainfall in mm of period 1981-2008

\section{Trend analysis}

Exploratory data analysis (EDA) and Trend analysis of annual means

Before performing time series analysis for a variable, it was customary to apply EDA to explore, understand and present data and to find any outliers visually. Thus, time series plot and box plot of annual means for weighted areal rainfall (AMWAR) were constructed and given in figure 3 and 4 . A visual inspection of the time series plot (Figure 3) indicated that an upward trend in the annual mean weighted areal rainfall could exist. The box-plot (Figure 4) showed that the data slightly departed from a normal distribution with single outlier and no extreme values. Two non-parametric tests of normality by Kolmogorov-Smirnov and Shapiro-Wilk (K-S) detected normality of the variable $(\mathrm{P}>0.05)$. Although a parametric test for trend was likely to be more powerful than the non-parametric tests in the analysis of data, both types of tests were more preferable than single test. When Spearman and Mann-Kendal tests for trend were applied at 99 percent confidence interval, both tests showed the identical results (Table 1 and see the note) that there was a significant linear positive trend over the period of 19812008. A temporal trend in data was also examined by use of regression

\section{Trend analysis of monthly data}

January to December (Table 2) refer annual mean weighted areal rainfall for the period of 1981-2008 for each of 12 months (seasons). Boxplots of each of 12 months (Figure 6) showed positively skewed shape, indicating departures from normality with some outliers and extreme values.

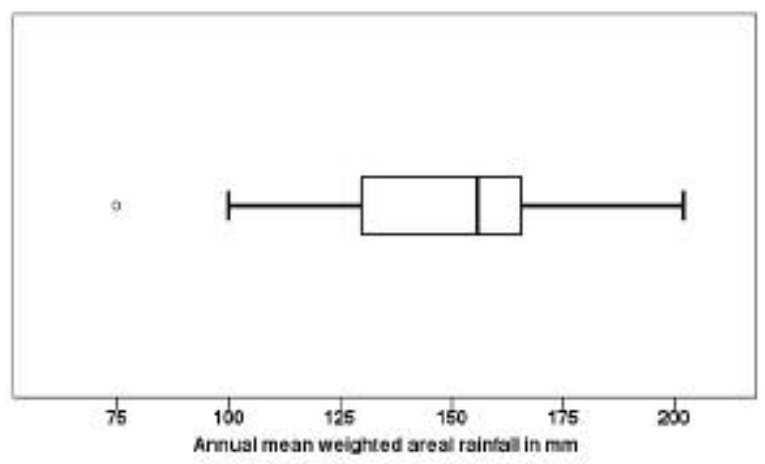

Fig.4. Box plot of Annual mean weighted areal rainfall in $\mathrm{mm}$ 
Rajendra Man Shrestha and Azaya Bikram Sthapit/Temporal variation of Rainfall......

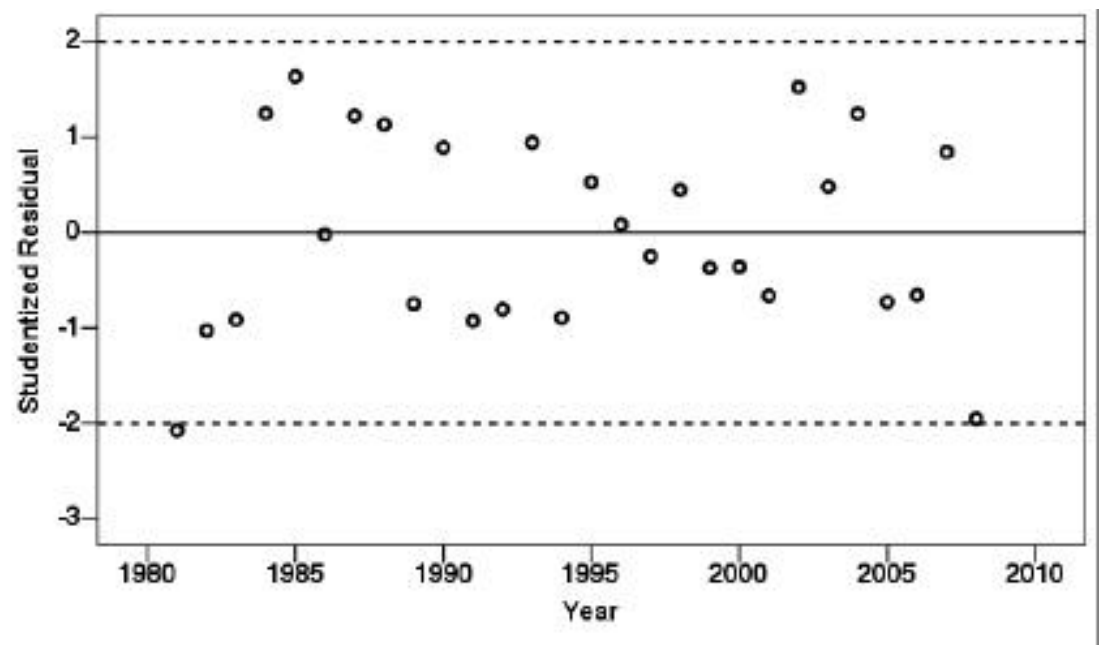

Fig.5. Scatter plots of studentized residuals against year

Table 1. Results of some parametric and non-parametric Tests

\begin{tabular}{ll|l|l|l|l}
\hline & Test statistic $(Z)$ & \multicolumn{2}{l|}{$\begin{array}{l}\text { Critical values } \\
\text { (Statistical table) }\end{array}$} & Result \\
\hline & & $\mathrm{a}=0.1$ & $\mathrm{a}=0.05$ & $\mathrm{a}=0.01$ & \\
Mann-Kendall & 2.628 & 1.645 & 1.96 & 2.576 & $\mathrm{~S}(0.01)$ \\
Spearman's Rho & 2.457 & 1.645 & 1.96 & 2.576 & $\mathrm{~S}(0.05)$ \\
Linear regression & $3.879(\mathrm{t})$ & 1.706 & 2.056 & 2.779 & $\mathrm{~S}(0.01)$ \\
Cumulative deviation & 1.426 & 1.116 & 1.236 & 1.452 & $\mathrm{~S}(0.05)$ \\
\hline
\end{tabular}

Note: Kendall's tau $=2.65$, Spearman's rho $=0.473$, Pearson's coefficient of correlation $=0.605$; Regression coefficient (b) $=2.176 \mathrm{~mm}$ per year; Durbin-Watson $\mathrm{d}=1.781, \mathrm{~d}_{\mathrm{L}}=1.33 \& \mathrm{~d}_{\mathrm{U}}=1.48$ for $\mathrm{n}=28$ and $\mathrm{a}=0.05$ (level of significance). Pvalue of K-S Normality test $=0.200$; $t$ stands for $t$-statistic. Cumulative deviation implies: Data show a statistically significant step jump and Mean of 1981-1994 < Mean of 1994-2008. "NS" stands for non-significant and "S" for significant

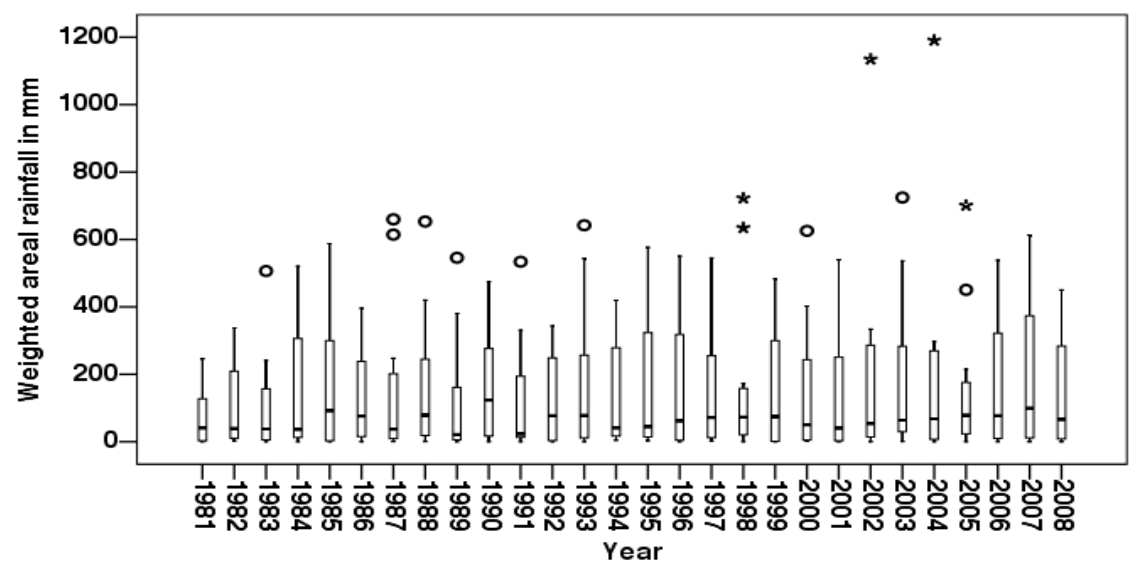

Fig.6. Boxplots of individual years from 1981 to 2008 
Nepal Journal of Science and Technology Vol. 16, No.1 (2015) 31-40

Table 2. Results of Mann-Kendall test for 12 seasons

\begin{tabular}{l|l|l|l|l|l|ll}
\hline Month & Tau & $\mathbf{Z}$ & $\mathbf{a}=\mathbf{0 . 1 0}$ & $\mathbf{a = 0 . 0 5}$ & $\mathbf{a = 0 . 1 0}$ & Decision \\
\hline January & 0.2766 & 0.257 & 1.645 & 1.96 & 2.576 & $\mathrm{NS}$ \\
February & 0.0000 & 0.000 & 1.645 & 1.96 & 2.576 & $\mathrm{NS}$ \\
March & 0.5137 & 0.494 & 1.645 & 1.96 & 2.576 & $\mathrm{NS}$ \\
April & 1.3830 & 1.363 & 1.645 & 1.96 & 2.576 & $\mathrm{NS}$ \\
May & 0.7508 & 0.731 & 1.645 & 1.96 & 2.576 & $\mathrm{NS})$ \\
June & 2.2918 & 2.272 & 1.645 & 1.96 & 2.576 & $\mathrm{~S}(0.05)$ \\
July & 1.8176 & 1.798 & 1.645 & 1.96 & 2.576 & $\mathrm{~S}(0.05)$ \\
August & 1.4225 & 1.403 & 1.645 & 1.96 & 2.576 & $\mathrm{NS}$ \\
September & 1.1459 & 1.126 & 1.645 & 1.96 & 2.576 & $\mathrm{NS}$ \\
October & 0.9483 & 0.929 & 1.645 & 1.96 & 2.576 & $\mathrm{NS}$ \\
November & 0.7508 & 0.73 & 1.645 & 1.96 & 2.576 & $\mathrm{NS}$ \\
December & -1.0471 & -1.027 & 1.645 & 1.96 & 2.576 & $\mathrm{NS}$ \\
\hline
\end{tabular}

"NS" stands for non-significant and "S" for significant.

Non-parametric Mann-Kendall is more appropriate for trend analysis for annual mean weighted areal rainfall for 12 months. Results of the seasonal Kendall trend tests are given in tables 1-2. The results indicated that there was an increasing trend in summer monsoon season (June and July) while other seasons/months had no significant temporal effect. Although December showed a decreasing trend in dry season, it was insignificant in nature.

\section{Conclusion}

Understanding of rainfall pattern is a subject of ongoing concern. An important goal of this study is to identify tendencies of the rainfall patterns that will help to recognize some determinants affecting such rainfall patterns from the normal condition. The determinants may be ENSO effect or ITCZ effect or large scale climatological variables that may change the rainfall pattern on the study site. However, despite these effects, there is an important temporal effect on it. Seasonality is a crucial part of the changing the rainfall pattern. Trend analysis for annual mean as well as monthly data of weighted areal rainfall was performed. Non-parametric Mann-Kendall test, Spearman's rho and linear regression methods were used after performing exploratory data analysis (EDA). EDA showed the normality nature of the annual mean of the stationary time series but non-normality nature along with some outliers and extreme values for monthly data over the period of 1981-2008. All trend analysis tools evidenced that there was a significant upward trend in the rainfall pattern in the Bagmati River basin. By the regression method, the rate of increase of the rainfall found to be $2.17 \mathrm{~mm}$ per year on the average. If such increasing trend of the rainfall persists in future, there would be deadly flooding in the study site. Trend analysis of monthly time series was also analyzed by MannKendall tool. The results showed an upward trend in the summer monsoon season (June and July) while the other monsoon seasons/months had no significant effect on temporal variation. It indicates that there would be heavy rainfall in this season if the increasing trend persists . The study, therefore, offers remarkable insights and new perspective for policy makers and planners to make appropriate strategies in the context of the ever increasing rainfall pattern, especially in the summer monsoon season. Finally, this study motivates all of us in finding the major determining factors that would induce change adversely in the rainfall pattern of the Bagmati River basin in future.

\section{Acknowledgements}

The author acknowledges the University Grants Commission, Sanothimi, Bhaktapur for providing PhD scholar grants which was helpful for conducting the research work.

\section{References}

Babel, M.S., S.P. Bhusal, S.M.Wahid and A. Agrawal. 2013. Climate Change and Water Resources in the Bagmati River Basin, Nepal. Theoretical and Applied Climatology 112:3-4.

Barros, A.P., M. Joshi, J. Putkonen and D.W. Burbank. 2000. A study of the 1999 monsoon rainfall in a mountainous region in central Nepal using TRMM products and rain gauge observations. Geophysical Research Letters 27: 3683-3686.

Barros, A.P. and T.J. Lang. 2003. Monitoring the monsoon in the Himalayas: observations in central Nepal, June 2001. Monthly Weather Review 131: 1408-1427. 
Rajendra Man Shrestha and Azaya Bikram Sthapit/Temporal variation of Rainfall......

Bookhagen ,B. and D.W. Burbank. 2006. Topography, relief, and TRMM-derived rainfall variations along the Himalaya. Geophysical Research Letters 33 (L08405). doi:10.1029/2006GL026037, 2006

Chalise, SR.1994. Mountain Environments and Climate Change in the Hindu Kush- Himalayas. In: Mountain Environments in Changing Climate (ed.M. Beniston, ), London, pp.382-404.

Chaulagain, N.P. 2006. Impacts of Climate Change on Water Resources of Nepal. The Physical and Socio Economic. University of Flensberg, Germany.

Critchfield, H.J.2002. General Climatology, $4^{\text {th }}$ edition. Prentice- Hall of India, New Delhi, 453pp.

Dickey, D.A. and W.A. Fuller. 1979.Distribution of the Estimators for Autoregressive Time Series with a Unit Root, J. Am. Stat. Association 74:427 - 431.

Graedel, T.E. and P.J. Crutzen.1993. Atmospheric Change: An earth system perspective. W.H. Freeman and Company, New York, pp446.

Grayson, R.B., R.M. Argent, R. J. Nathan,T.A. Mc Mahon and R. Mein. 1996. Hydrological Recipes: Estimation Techniques in Australian Hydrology. Cooperative Research Centre for Catchment Hydrology. Australia, pp 12.

IPCC. 2001a. Climate Change 2001: Synthesis Report. Contribution of Working Groups I, II and III to the Third Assessment Report of the Intergovernmental Panel on Climate Change (Eds. Watson RT et al.) Cambridge, pp 516.

IPCC. 2001c. Climate Change 2001: The Scientific Basis. Contribution of Working Group I to the Third Assessment report of the Intergovernmental Panel on Climate Change (Eds. JT Houghton, Y Ding, DJ Griggs, M Nouger, PJ Van der Linden, X Dai, K Maskell, CA Johnson). Cambridge University Press, Cambridge, pp881.

Jha, R. 2002. Potential Erosion Map for Bagmati Basin Using GRASS GIS. Proceedings of the Open Source GIS-GRASS Users conference; Trento, 2002. Italy.

Kothyari, U.C. and V.P.Singh. 1996. Rainfall and temperature trends in India.Hydrological Processes. 10: $357-372$.

Kwiatkowski, D., P.C. B. Philips, P. Schmidt and Y. Shin. 1992. Testing the Null Hypothesis of Stationarity against the Alternative of Unit Root. J. Econometrics 54: $159-178$.

Lang,T.J. and A.P. Barros. 2002. An investigation of the onsets of the 1999 and 2000 monsoons in central Nepal. Monthly Weather Review 130: 1299-1316.

Mairura, F., M. O. Kisaka, M. M. Muna, F.K. Ngetich, N. Mugwe and D. Mugendi. 2015. Rainfall Variability, Drought Characterization, and Efficacy of Rainfall Data

Reconstruction: Case of Eastern Kenya. Advances in Meteorology 2015:16 pages. doi.org/10.1155/2015/ 380404.
Nakawo, M., K. Fujita, Y. Ageta, K. Shankar, A. P. Pokhrel and Y. Tandong.1997. Basic studies for assessing the impacts of the global warming on the Himalayan cryosphere, 1994-1996. In: Bulletin of Glacier Research 15, Data center for glacier research, Japanese society for snow and ice, pp. 53-58.

Nayava, J.L. 1980. Rainfall in Nepal. The Himalayan Review.12:1980.

Parry, M.L., O.F. Canziani, J.P. Palutikof, P.J. Vander Linden and C.E Hanson, Eds.2007.Climate Change 2007: Contribution of Working Group II to the Fourth Assessment Report of the Intergovernmental Panel on Climate Change. Cambridge University Press, Cambridge, United Kingdom and New York, NY, USA.

Rupa Kumar, K., K. Krishna Kumar, A.G. Ashrit, S.K. Patwardhan and G.B.Pant.2002. Climate change in India: Observations and model projections. In: Climate change and India: Issues, concerns and opportunities (Eds. Shukla et al.), pp.25-76.

Shankar, K. and P.B Shrestha.1985.Climate. In: Nepal Nature's Paradise: Insight into diverse facets of Topography, flora and ecology (Ed. TC. Majupuria, ), White Lotus Co.Ltd, Bangkok, pp. 39-44.

Sharma, K.P., B. Moore III and C.J. Vorosmarty. 2000a. Anthropogenic, Climatic and Hydrologic Trends in the Koshi Basin, Himalaya. In: Climatic Change 47, Kluwer Academic Publishers, Dordrecht, the Netherlands, pp. 141-165.

Sharma, K.P. and N.R. Adhikari. 2004. Hydrological Estimates in Nepal. Main Report and Appendix I, His Majesty of Government, Ministry of Science and Technology, DHM.

Shrestha, A.B., C.P. Wake, J.E. Dibb, and P.A. Mayewski. 2000.Rainfall fluctuation in the Nepal Himalaya and its vicinity and relationship with some large scale climatology parameters. In: International Journal of Climatology 20:317-327.

Shrestha, M.L. 2000. Interannual variation of summer monsoon rainfall over Nepal and its relation to Southern Oscillation Index. Meteorology and Atmospheric Physics 75: 21- 28.

Shrestha, M. L., S. K. Baidya and M. S. Muhammad .2008. Trends in Daily Climatic Extremes of Temperature and Precipitation in Nepal. Journal of Hydrology and Meteorology 5(1):38-51.

Shrestha, D., P. Singh, and K. Nakamura. 2012. Spatiotemporal variation of rainfall over the central Himalayan region revealed by TRMM Precipitation Radar. Journal of Geophysical Research 117 (D22106). DOI:10.1029/2012JD018140

Shrestha, M.L., M.M. Sheik, N. Manzoor, J. Asraf, M. Adnan, D.Collins, S. Hameed, M.J.Manton, A.U.Ahmed, S.K. Baidya, H.P. Borgaonkar, N.Islam, D.Jayasinghearachchi, D.R. Kothawale, K.H.M.S. Premlal, and J.V. Revadekar.2014.Trends in extreme 
Nepal Journal of Science and Technology Vol. 16, No.1 (2015) 31-40

daily rainfall and temperature indices over South Asia. International Journal of Climatology 35:1625-1637. DOI : $10.1002 /$ joc.4081

Shrestha, M.L., J. Panthi, S. Aryal, N.Y.Krakauer, S.M.Pradhanang, T.Lakhanjar, A.K.Jha, M.Sharma and R. Karki .2015. Spatial and Temporal Variability of Rainfall in the Gandaki River Basin of Nepal Himalaya. Climate 3(210-226). DOI:10.3390/cli3010210

Sigdel, M. and M. Ikeda. 2012. Summer Monsoon Rainfall over Nepal Related with Large Scale Atmospheric
Circulations. Journal of Earth Science \& Climate Change 3(2): 112.

(DOI: 10.4172/2157-7617.100012).

Varela- Lopes, G.E. and L.C.B. Molion. 2014.rainfallPatterns in Cape Verde Islands: Santiago Island Case Study. Atmospheric and Climate Sciences 4:854-865.

Yadav, R.K., K.R. Kumar and M. Rajeevan. 2007. Role of Indian Ocean Sea Surface temperature in modulating northwest Indian winter rainfall variability. Theoretical and Applied Climatology 87:73-83. 